\title{
The ruthenium pyrochlore $\mathrm{Dy}_{2} \mathrm{Ru}_{2} \mathrm{O}_{7}(\mathrm{~s})$ : Stability and calorimetry
}

\author{
Aparna Banerjee ${ }^{1}$
}

Received: 2 March 2020 / Accepted: 22 May 2020 / Published online: 2 June 2020

(c) Springer Nature Switzerland AG 2020

\begin{abstract}
The $4 d$ transition metal ruthenium pyrochlore $\mathrm{Dy}_{2} \mathrm{Ru}_{2} \mathrm{O}_{7}(\mathrm{~s})$ was synthesized by solid state reaction route. High temperature studies on the ternary oxide $\mathrm{Dy}_{2} \mathrm{Ru}_{2} \mathrm{O}_{7}(\mathrm{~s})$ an important ferroelectric and magnetic material, has been carried out using solid-state electrochemical cell, with calcia stabilized zirconia electrolyte and the reversible electromotive force were measured. The Gibbs energy of formation of $\mathrm{Dy}_{2} \mathrm{Ru}_{2} \mathrm{O}_{7}(\mathrm{~s})$ from elements in their standard state, is:
\end{abstract}

$\left\{\Delta_{\mathrm{f}} \mathrm{G}^{\circ}\left(\mathrm{Dy}_{2} \mathrm{Ru}_{2} \mathrm{O}_{7}, \mathrm{~s}\right) /\left(\mathrm{kJ} \mathrm{mol}^{-1}\right) \pm 4.4\right\}=-2505.0+0.627 \cdot(T / \mathrm{K}) ;$

$(859 \leq T / K \leq 1136)$.

The standard molar heat capacity $C_{p, m}^{\circ}(T)$ of $\mathrm{Dy}_{2} \mathrm{Ru}_{2} \mathrm{O}_{7}(\mathrm{~s})$, measured using a differential scanning calorimeter run in the heat flux mode as a function of temperature. The values fitted to a polynomial expression can be represented by:

$$
\begin{aligned}
& C_{\mathrm{p}, \mathrm{m}}^{\circ}\left(\mathrm{Dy}_{2} \mathrm{Ru}_{2} \mathrm{O}_{7}, \mathrm{~s}, \mathrm{~T}\right)\left(\mathrm{J} \mathrm{K}^{-1} \mathrm{~mol}^{-1}\right) \\
& \quad=235.09+3.99 \times 10^{-2} \mathrm{~T}(\mathrm{~K})-10.53 \times 10^{5} / \mathrm{T}^{2}(\mathrm{~K}) .
\end{aligned}
$$

Stability of $\mathrm{Dy}_{2} \mathrm{Ru}_{2} \mathrm{O}_{7}(\mathrm{~s})$ and high temperature thermodynamic functions of this transition metal pyrochlore were determined for the first time, an important fundamental study.

Keywords Transition metal oxide · Calorimetry · Heat capacity · High temperature solid-state electrochemical cell . Pyrochlores $\cdot \mathrm{Dy}_{2} \mathrm{Ru}_{2} \mathrm{O}_{7}(\mathrm{~s})$

\section{Introduction}

Pyrochlores with the general structural formula $\mathrm{A}_{2} \mathrm{~B}_{2} \mathrm{O}_{7}$, wherein $A$ is a trivalent rare earth ion and $B$ is $3 d, 4 d$ or $5 d$ transition metal ion, have evoked a lot of interest amongst researchers for their varied applications such as in "radwaste matrices" [1], as catalysts [2], in oxygen evolution reactions [3] and thermal barrier coatings [4]. Pyrochlores also show interesting electronic and magnetic properties $[5,6]$. Pyrochlores are good refractory materials, possess chemical durability and have structural flexibility and are able to incorporate trivalent lanthanides and tetravalent actinides, hence the acronym rad-waste matices $[1,7]$. Catalytic properties of $\mathrm{A}_{2} \mathrm{Ru}_{2} \mathrm{O}_{7}$ were explored by Ashcroft and co-workers and used for the selective oxidation of methane to synthesis gas [2]. Pyrochlore electrocatalysts have been proposed by Parrondo et al. [8] for efficient alkaline water electrolysis. Recently the high performance pyrochlore type $\mathrm{Y}_{2} \mathrm{Ru}_{2} \mathrm{O}_{7}(\mathrm{~s})$ was proposed as an electrocatalysts for oxygen evolution reaction in acidic medium by Kim et al. [3]. $\mathrm{La}_{2} \mathrm{Zr}_{2} \mathrm{O}_{7}(\mathrm{~s})$ pyrochlore was proposed for thermal barrier coatings and its thermal stability was studied by annealing and thermal cycling by Cao et al. [4].

Aparna Banerjee, aparna_baner@yahoo.com; aparnab@barc.gov.in | ${ }^{1}$ Fuel Chemistry Division, Bhabha Atomic Research Centre, Mumbai 400 085, India. 
The electronic properties of the pyrochlore oxides wherein the transition metal is ruthenium(IV), range from Pauli paramagnets to semiconductors $[5,9]$. Xu et al. [10] observed ferroelectricity in the double pyrochlore $\mathrm{Dy}_{2} \mathrm{Ru}_{2} \mathrm{O}_{7}$. Soderholm and Greedan investigated the magnetic properties of $\mathrm{Ln}_{2} \mathrm{~V}_{2} \mathrm{O}_{7}(\mathrm{~s})(\mathrm{Ln}=$ rare earth) pyrochlores and concluded that they were ferromagnetic semiconductors [11]. Nature of spin freezing transition of geometrically frustrated pyrochlore systems $\mathrm{Ln}_{2} \mathrm{Ru}_{2} \mathrm{O}_{7}$ ( $\mathrm{Ln}=$ rare earth element) were first investigated by lto et al. [12]. Taira et al. [6] carried out magnetic susceptibility measurements on the heavy rare earth ruthenate pyrochlores $\mathrm{Ln}_{2} \mathrm{Ru}_{2} \mathrm{O}_{7}$ $(\mathrm{Ln}=\mathrm{Gd}-\mathrm{Yb})$. They observed a lambda type anomaly in the specific heat versus temperature plot at $103 \mathrm{~K}$ for $\mathrm{Dy}{ }_{2} \mathrm{Ru}_{2} \mathrm{O}_{7}$ and a ferromagnetic transition below $1.8 \mathrm{~K}$. Yao and coworkers synthesized $\mathrm{Ln}_{2} \mathrm{Ru}_{2} \mathrm{O}_{7}$ pyrochlore compounds by a hydrothermal method and measured magnetic susceptibility at low temperature [13]. Magnetic measurements on the $\mathrm{Ho}_{2} \mathrm{Ru}_{2} \mathrm{O}_{7}$ and $\mathrm{Dy}_{2} \mathrm{Ru}_{2} \mathrm{O}_{7}$ pyrochlores were carried out by Bansal et al. [14] to investigate the possibility of spin ice type magnetism in these systems and concluded from their investigations that these pyrochlore systems have a magnetic behavior similar to other spin ice systems.

Several properties of pyrochlores has been studied by researchers, however, high temperature studies on these systems are lacking. As part of systematic studies, to determine thermodynamic properties on the ternary oxides in the $\mathrm{Ln}-\mathrm{Ru}-\mathrm{O}$ systems in our laboratory, thermodynamic studies on the oxide $\mathrm{Dy}_{2} \mathrm{Ru}_{2} \mathrm{O}_{7}(\mathrm{~s})$ were carried out. A study of thermodynamic properties gives information on the thermodynamic stability domain of these compounds. From the thermodynamic properties of $\mathrm{Dy}_{2} \mathrm{Ru}_{2} \mathrm{O}_{7}(\mathrm{~s})$ process conditions can be devised to extract the valuable ruthenium from scrap and electronic waste. Further from the thermodynamic data of ternary oxides, phase diagrams of quaternary systems containing these elements can be readily computed. Hence based on phase relations, the Gibbs energy of formation of $\mathrm{Dy}_{2} \mathrm{Ru}_{2} \mathrm{O}_{7}$ (s) was determined by an in house fabricated electrochemical cell using calcia stabilized zirconia (CSZ) as the solid electrolyte. The heat capacity of $\mathrm{Dy}_{2} \mathrm{Ru}_{2} \mathrm{O}_{7}(\mathrm{~s})$ was measured in the temperature range from 174 to $305 \mathrm{~K}$ using a differential scanning calorimeter (DSC-131). Other thermodynamic parameters at elevated temperatures were evaluated from these experimental data.

\section{Materials and methods}

\subsection{Materials}

The starting material $\mathrm{Dy}_{2} \mathrm{O}_{3}(\mathrm{~s})(0.9985$ mass fraction, Leico Industries Inc. U.S.A.) was preheated to remove all traces of moisture. $\mathrm{Dy}_{2} \mathrm{Ru}_{2} \mathrm{O}_{7}(\mathrm{~s})$ was synthesized from stoichiometric proportions of preheated $\mathrm{Dy}_{2} \mathrm{O}_{3}(\mathrm{~s})$ and $\mathrm{RuO}_{2}(\mathrm{~s})(0.998$ mass fraction, Prabhat Chemicals, India). The oxides were ground and the mixture was then pelletized using a die of tungsten carbide, sealed in an evacuated quartz ampoule and heated to $T=1400 \mathrm{~K}$ for $24 \mathrm{~h}$. The possibility of interaction of the sample material with quartz ampoule was prevented by stacking pellets in the ampoule and using the pellet in contact with the quartz as the sacrificial pellet as described earlier [15]. The values of the interplanar $d$ spacing obtained for $\mathrm{Dy}_{2} \mathrm{Ru}_{2} \mathrm{O}_{7}(\mathrm{~s})$ using STOE diffractometer with $\mathrm{Cu}-\mathrm{K}_{\mathrm{a}}$ radiation $(\lambda=1.5406 \hat{A})$ is in good agreement with those reported in JCPDS file number \#82-2039 [16].

The oxide $\mathrm{Dy}_{2} \mathrm{Ru}_{2} \mathrm{O}_{7}(\mathrm{~s})$ lies on the tie line between $\mathrm{Dy}_{2} \mathrm{O}_{3}(\mathrm{~s})$ and $\mathrm{RuO}_{2}(\mathrm{~s})$ in the $\mathrm{Dy}-\mathrm{Ru}-\mathrm{O}$ system. Phase relations were explored of different phase mixtures of oxide phases and metal, by equilibration at $1200 \mathrm{~K}$ and phase analysis of quenched samples. The phase composition of $\left\{\mathrm{Dy}_{2} \mathrm{O}_{3}(\mathrm{~s})+\mathrm{Dy}_{2} \mathrm{Ru}_{2} \mathrm{O}_{7}(\mathrm{~s})+\mathrm{Ru}(\mathrm{s})\right\}$ remained the same by equilibration. A phase mixture of $\left\{\mathrm{Dy}_{2} \mathrm{O}_{3}(\mathrm{~s})+\mathrm{Dy}_{2} \mathrm{Ru}_{2} \mathrm{O}_{7}(\right.$ s) $+\mathrm{Ru}(\mathrm{s})\}$ was pelletized into a pellet with the following dimension: $10 \mathrm{~mm}$ diameter and $2.5 \mathrm{~mm}$ in thickness in the molar ratio of 1:1:2 using tungsten carbide die at a pressure of $100 \mathrm{MPa}$. The pellet was sintered in high purity argon gas atmosphere at $T=1000 \mathrm{~K}$ for several hours and thereafter used for e.m.f. measurements.

\subsection{The oxide cell assembly}

A double compartment cell assembly with 0.15 mol fraction CSZ solid electrolyte tube with one end closed and flat was used to separate the gaseous environments of the two electrodes for electrochemical measurements and was inhouse fabricated. Schematic diagram of the experimental set-up used and its description is shown in an earlier publication [17]. The cover gas of the cell was argon, flowing at a rate of $1 \mathrm{dm}^{3} \mathrm{~h}^{-1}$, purified by passing through towers containing the reduced form of BASF catalyst, molecular sieves and magnesium perchlorate. The sample electrode compartment was initially evacuated and flushed with argon gas. This procedure was repeated several times while simultaneously heating the cell to around $573 \mathrm{~K}$ to dispel all moisture and other atmospheric gases present in the electrode compartment. The argon gas was bubbled out at a steady rate through an oil bubbler without disturbing the equilibrium at the working electrode. The argon cover gas was directed via an alumina guide tube to the working electrode. A Faraday cage was placed between the cell assembly and the furnace, the cage was grounded to minimize induced electro-motive force (e.m.f.) on the cell leads. Platinum leads sheathed in alumina were used to measure the e.m.f. Synthetic dry air was used as the reference electrode that ensured moisture free air. Temperature of the cell was measured by using a calibrated chromel-alumel 
thermocouple placed near the pellet. The e.m.f. of the cell was measured when its value was steady for $2-3 \mathrm{~h}$ using a high impedance Keithley 614 electrometer. Measurements at low temperatures were made after equilibrating the cell for more than $12 \mathrm{~h}$. Voltages were reproducible in subsequent heating cycles. E.m.f. was measured after initially equilibrating the galvanic cells at $1000 \mathrm{~K}$ for at least $24 \mathrm{~h}$. The following cell configuration was employed in the present study:

Cell I: (-)Pt/\{Dy $\left.\mathrm{O}_{3}(\mathrm{~s})+\mathrm{Dy}_{2} \mathrm{Ru}_{2} \mathrm{O}_{7}(\mathrm{~s})+\mathrm{Ru}(\mathrm{s})\right\} / / \mathrm{CSZ} / /$ $\mathrm{O}_{2}\left(p\left(\mathrm{O}_{2}\right)=21.21 \mathrm{kPa}\right) / \mathrm{Pt}(+)$.

The reversibility of the solid-state electrochemical cell was checked by micro-coulometric titration in both directions. A small quantity of current was passed through the cell in either direction. Removal of the applied current returned the cell e.m.f. to its original value. The e.m.f. of the cell was also found to be independent of flow rate of the inert gas passing over the electrodes. The range of permissible oxygen partial pressures for purely ionic conduction for CSZ electrolytes is about $10^{-20} \mathrm{~Pa}$ at $1000 \mathrm{~K}$ and $10^{-13} \mathrm{~Pa}$ at $1273 \mathrm{~K} \mathrm{[18]}$. The oxygen partial pressure of the above designed cell falls within this range.

\subsection{Measurement of low temperature heat capacity of $\mathrm{Dy}_{2} \mathrm{Ru}_{2} \mathrm{O}_{7}(\mathrm{~s})$}

Heat capacity measurements were carried out using a heat flux type differential scanning calorimeter (Model: DSC-131, Setaram Instrumentation, France). The transducer of DSC131 has been designed using the technology of the plate shaped DSC rods made of chromel-costantan. It is arranged in a small furnace with a metal resistor of low-thermal inertia so as to produce high heating and cooling rates, thereby providing for high speed experiments. The transducer possesses very good sensitivity also over the entire temperature range (100-950 K). The temperature calibration of the calorimeter was carried out by: "the phase transition temperature of National Institute of Standards and Technology (NIST) reference materials (mercury: $T_{\text {fus }}=234.316 \mathrm{~K}$; gallium: $T_{\text {fus }}=302.914 \mathrm{~K}$; indium: $T_{\text {fus }}=429.748 \mathrm{~K}$; $\operatorname{tin} T_{\text {fus }}=505.078 \mathrm{~K}$ ) and AR grade samples ( $n$-pentane: $T_{\text {fus }}=140.490$; cyclohexane: $T_{\text {fus }}=280.1 \mathrm{~K}, T_{\text {trs }}=190.0 \mathrm{~K}$; deionised water: $T_{\text {fus }}=273.160 \mathrm{~K}$." Heat calibration of the calorimeter was carried out from the enthalpies of transition of the reference materials as given in an earlier publication [19]. For the determination of heat capacity, NIST synthetic sapphire (SRM 720) in the powder form was used as the reference material [20]. Heat capacity of the oxide was determined in the temperature range from 174 to $305 \mathrm{~K}$.

The classical three-step method in the continuous heating mode was followed in this study to measure the specific heat in the first temperature range from 126 to $284 \mathrm{~K}$. Liquid nitrogen was used in the low temperature range and was fed to the DSC instrument via a cryogenic device (jar). Heat flow as a function of temperature was measured at a heating rate of $5 \mathrm{~K} \mathrm{~min}^{-1}$ with high purity helium as a carrier gas with a flow rate of $2 \mathrm{dm}^{3} \mathrm{~h}^{-1}$ as illustrated in the literature [21]. Three sets of experiments were carried out, performed under identical experimental conditions viz. heating rate, carrier gas flow rate, and delay time and temperature range. Two empty, aluminum crucibles with lids of identical masses were selected for the sample and reference cells. In the first experiment both the sample and reference cells were empty. The heat flow versus temperature was measured at a heating rate of $5 \mathrm{~K} \mathrm{~min}^{-1}$. In the second set of experiments weighed synthetic sapphire (SRM-720) was loaded in the sample cell the reference side was empty and the heat flow versus temperature was measured. In the third set of experiments, sample was weighed and loaded in the sample cell, reference cell being empty and the heat flow as a function of temperature was measured. About $300-350 \mathrm{mg}$ of the sample was used for the heat capacity measurements.

The heat capacity of the sample under investigation was calculated by a simple comparison of the heat flow rates in three runs. If $T_{\mathrm{j}}$, represents the initial temperature, the temperature interval step is chosen between $T_{\mathrm{j}}$ and $T_{\mathrm{j}+1}$, we define: $T_{\mathrm{j}}=T_{\mathrm{i}}+\Delta T$ and $T_{\mathrm{j}+1}=T_{\mathrm{i}}+(\mathrm{j}+\mathrm{i}) \Delta T$. For the calculation of heat capacity of the sample the expression used was:

$$
\begin{aligned}
C_{\mathrm{p}}\left(T_{\mathrm{j}}\right)_{\text {sample }}= & \left\langle\left(\mathrm{HF}_{\text {sample }}-\mathrm{HF}_{\text {blank }}\right)\right\rangle /\left\langle\left(\mathrm{HF}_{\text {Ref }}-\mathrm{HF}_{\text {blank }}\right)\right\rangle \\
& \cdot\left(\mathrm{M}_{\text {Ref }} / \mathrm{M}_{\text {sample }}\right)\left\langle C_{\mathrm{p}}\left(T_{\mathrm{j}}\right)_{\text {Ref }}\right\rangle
\end{aligned}
$$

where $\mathrm{HF}_{\text {blank }}, \mathrm{HF}_{\text {Ref }}$ and $\mathrm{HF}_{\text {sample }}$ represent heat flow during first, second and third runs respectively. $C_{\mathrm{p}}\left(T_{\mathrm{j}}\right)_{\text {sample }}$ and $C_{p}\left(T_{j}\right)_{\text {Ref }}$ represent the heat capacities of sample and reference material in $\mathrm{J} \mathrm{K}^{-1} \mathrm{~g}^{-1}$ and $\mathrm{M}_{\text {sample }}$ and $\mathrm{M}_{\text {Ref }}$ represent the mass of sample and reference, respectively. The heat capacity thus obtained was then converted to $\mathrm{J} \mathrm{K}^{-1} \mathrm{~mol}^{-1}$. The accuracy of measurements was checked by measuring heat capacity of $\mathrm{Fe}_{2} \mathrm{O}_{3}$ (s) (Alfa Aesar, mass fraction 0.998) and the values obtained were found to be within $\pm 3 \%$ in this temperature range as compared with the literature values [22] 


\section{Results and discussion}

\subsection{Solid-state electrochemical measurements using oxide cell}

E.m.f. of the electrochemical cell using an oxide electrolyte is related to the partial pressure of oxygen at the two electrodes and can be given by the relation:

$E=(R T / n F) \cdot \int_{p^{\prime}\left(\mathrm{O}_{2}\right)}^{p^{\prime \prime}\left(\mathrm{O}_{2}\right)} t\left(\mathrm{O}^{2-}\right) \cdot \mathrm{d} \ln p\left(\mathrm{O}_{2}\right)$

where " $E$, is the measured e.m.f. of the cell in volts, $R=8.3144 \mathrm{~J} \cdot \mathrm{K}^{-1} \cdot \mathrm{mol}^{-1}$ is the universal gas constant, $\mathrm{n}$ is the number of electrons participating in the electrode reaction, $F=96,485.3 \mathrm{C} \mathrm{mol}^{-1}$ is the Faraday constant, $T$ is the absolute temperature, $t\left(\mathrm{O}^{2-}\right)$ is the effective transference number of $\mathrm{O}^{2-}$ ion for the solid electrolyte and $p^{\prime \prime}\left(\mathrm{O}_{2}\right)$ and $p^{\prime}\left(\mathrm{O}_{2}\right)$ are the equilibrium oxygen partial pressures at the positive and negative electrodes respectively". The transport number of oxygen ion is nearly unity $\left(t\left(\mathrm{O}^{2-}\right)>0.99\right)$ at the oxygen pressures and temperatures covered in this study. Hence, the e.m.f. is directly proportional to logarithm of the ratio of partial pressures of oxygen at the electrodes:

$E=(R T / \mathrm{n} F) \cdot \ln \left\{p^{\prime \prime}\left(\mathrm{O}_{2}\right) / p^{\prime}\left(\mathrm{O}_{2}\right)\right\}$.

Thus,

$n F E=R T \ln p^{\prime \prime}\left(\mathrm{O}_{2}\right)-R T \ln p^{\prime}\left(\mathrm{O}_{2}\right)$,

where " $R T \ln p^{\prime \prime}\left(\mathrm{O}_{2}\right)$ is the oxygen chemical potential over the positive electrode and $R T \ln p^{\prime}\left(\mathrm{O}_{2}\right)$ is the oxygen chemical potential over the negative electrode".

In the Dy-Ru-O system, along the Ru-O binary, only one oxide $\mathrm{RuO}_{2}(\mathrm{~s})$ exists, and has a tetragonal structure. Along the Dy-O binary the only oxide is $\mathrm{Dy}_{2} \mathrm{O}_{3}(\mathrm{~s})$ and has a cubic structure. $\mathrm{Dy}_{2} \mathrm{Ru}_{2} \mathrm{O}_{7}(\mathrm{~s})$ with pyrochlore structure lies on the tie line of these two stable oxides. The following two, three phase regions were explored:

(a) $\mathrm{Dy}(\mathrm{s})+\mathrm{RuO}_{2}(\mathrm{~s})+\mathrm{Dy}_{2} \mathrm{Ru}_{2} \mathrm{O}_{7}(\mathrm{~s})$

(b) $\mathrm{Dy}_{2} \mathrm{O}_{3}(\mathrm{~s})+\mathrm{Ru}(\mathrm{s})+\mathrm{Dy}_{2} \mathrm{Ru}_{2} \mathrm{O}_{7}(\mathrm{~s})$.

In the three phase mixture (a) one of the components is metallic Dy(s). However this metal needs to be handled inside a glove box as it oxidizes easily to the very stable $\mathrm{Dy}_{2} \mathrm{O}_{3}(\mathrm{~s})$. Hence the phases involving $\mathrm{Ru}, \mathrm{Dy}_{2} \mathrm{O}_{3}(\mathrm{~s})$ and $\mathrm{Dy}_{2} \mathrm{Ru}_{2} \mathrm{O}_{7}(\mathrm{~s})$ were equilibrated and used as the working electrode. However the electrochemical cell had platinum lead wires and as there is considerable solid solubility of $\mathrm{Ru}(\mathrm{s})$ in metallic $\mathrm{Pt}(\mathrm{s})$ the e.m.f. of the cell was found to continuously drift. Hence prior to the experiments involving Cell (I) the following symmetric cell was setup:

$\mathrm{Pt} / \mathrm{Ru}(\mathrm{s})+\mathrm{RuO}_{2}(\mathrm{~s}) / / \mathrm{CSZ} / / \mathrm{Ru}(\mathrm{s})+\mathrm{RuO}_{2}(\mathrm{~s})$

In the above cell a thin gold foil was placed between the platinum lead wires and the binary phase mixture on either side and cycled for several days at $1150 \mathrm{~K}$. This not only enabled the gold foil saturated with ruthenium to bind with the platinum lead wire on either side but also gave a null e.m.f. Now the Cell(I) was setup with a phase mixture of $\mathrm{Dy}_{2} \mathrm{O}_{3}(\mathrm{~s}): \mathrm{Dy}_{2} \mathrm{Ru}_{2} \mathrm{O}_{7}(\mathrm{~s}): \mathrm{Ru}(\mathrm{s})$ in the molar ratio of 1:1:2 and used as the working electrode and air as the reference electrode.

The half-cell reaction at the cathode and the anode for the cell I in the oxide conducting domain of the electrolyte at elevated temperature can be given by:

$2 \mathrm{O}_{2}(\mathrm{~g})+8 \mathrm{e}^{-}=4 \mathrm{O}^{2-}$, (at the cathode)

and,

$\mathrm{Dy}_{2} \mathrm{O}_{3}(\mathrm{~s})+2 \mathrm{Ru}(\mathrm{s})+4 \mathrm{O}^{2-}=\mathrm{Dy}_{2} \mathrm{Ru}_{2} \mathrm{O}_{7}(\mathrm{~s})+8 \mathrm{e}^{-}$, (at the anode)

The net virtual cell reaction for the passage of eight Faradays of electricity obtained by combining the two half cell reactions is:

$\mathrm{Dy}_{2} \mathrm{O}_{3}(\mathrm{~s})+2 \mathrm{Ru}(\mathrm{s})+2 \mathrm{O}_{2}(\mathrm{~g})=\mathrm{Dy}_{2} \mathrm{Ru}_{2} \mathrm{O}_{7}(\mathrm{~s})$,

Within experimental uncertainty, the least square regression analysis of the e.m.f. gives:

$E / V( \pm 0.005)=0.8447-5.08 \times 10^{-4} \cdot(T / K) ;(859 \leq T / K \leq 1136)$.

The uncertainties quoted are the standard deviation in e.m.f. The variation of e.m.f. as a function of temperature is presented in Fig. 1. The $\Delta_{\mathrm{r}} G^{\circ}(T)$ for the reaction given in Eq. (7) involves the transfer of eight electrons and hence from Nernst equation we get:

$$
\begin{aligned}
\Delta_{\mathrm{r}} G^{\circ}(T)=-8 \mathrm{FE}= & \Delta_{\mathrm{f}} G^{\circ}\left\{\mathrm{Dy}_{2} \mathrm{Ru}_{2} \mathrm{O}_{7}(\mathrm{~s})\right\} \\
& -\Delta_{\mathrm{f}} G^{\circ}\left\{\mathrm{Dy}_{2} \mathrm{O}_{3}(\mathrm{~s})\right\}-2 R T \ln p\left(\mathrm{O}_{2}\right) .
\end{aligned}
$$

From Eqs. (7), (8) and (9) and literature value of $\Delta_{\mathrm{f}} G^{\circ}\left\{\mathrm{Dy}_{2} \mathrm{O}_{3}(\mathrm{~s})\right\}[23], \Delta_{\mathrm{f}} G^{\circ}$ of $\mathrm{Dy}_{2} \mathrm{Ru}_{2} \mathrm{O}_{7}(\mathrm{~s})$ has been obtained.

$$
\left\{\Delta_{\mathrm{f}} \mathrm{G}^{\circ}\left(\mathrm{Dy}_{2} \mathrm{Ru}_{2} \mathrm{O}_{7}, \mathrm{~s}\right) /\left(\mathrm{kJ} \mathrm{mol}^{-1}\right) \pm 4.4\right\}=-2505+0.627 \cdot(T / \mathrm{K}) \text {. }
$$

The error includes the standard deviation in e.m.f. and the uncertainty in the data taken from the literature. Gibbs energy of formation is a linear function of temperature within the experimental temperature range under consideration. The intercept and the slope of this equation correspond, respectively, to the average values of the standard molar enthalpy and entropy of formation of $\mathrm{Dy}_{2} \mathrm{Ru}_{2} \mathrm{O}_{7}(\mathrm{~s})$ in 


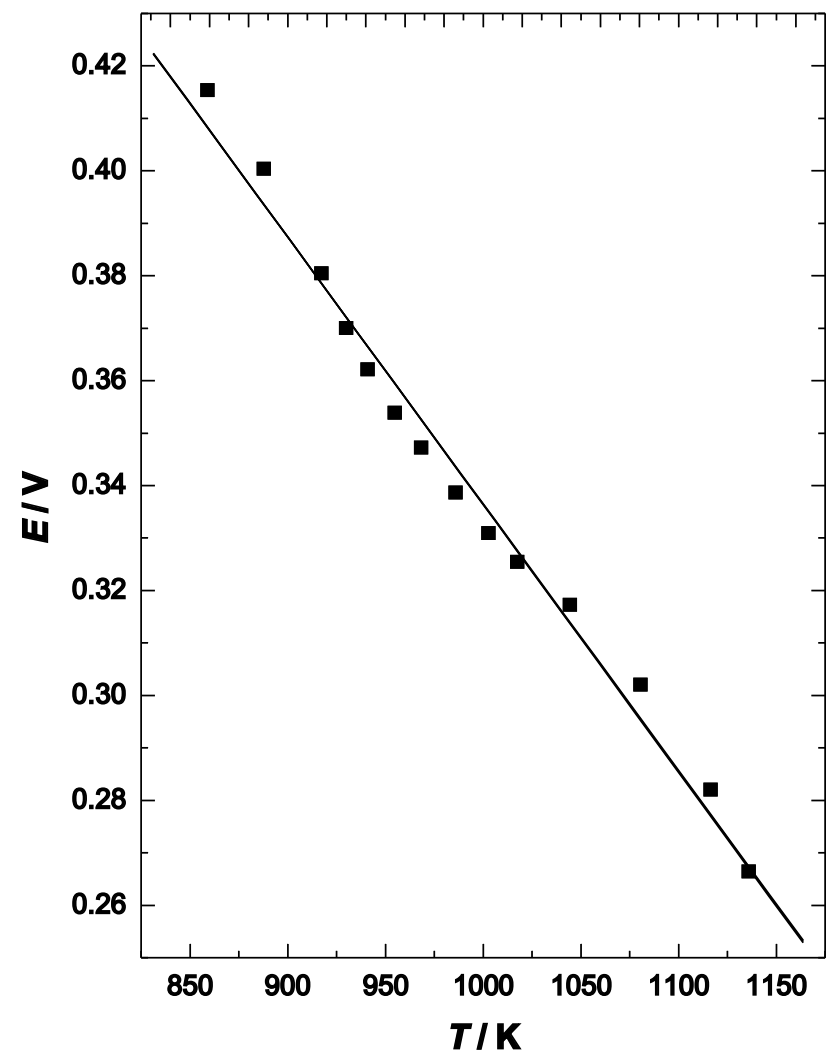

Fig. 1 Variation of e.m.f. as a function of temperature for the cell: $(-) \mathrm{Pt} /\left\{\mathrm{Dy}_{2} \mathrm{O}_{3}(\mathrm{~s})+\mathrm{Dy}_{2} \mathrm{Ru}_{2} \mathrm{O}_{7}(\mathrm{~s})+\mathrm{Ru}(\mathrm{s})\right\} / / \mathrm{CSZ} / / \mathrm{O}_{2}\left(p\left(\mathrm{O}_{2}\right)=21.21 \mathrm{kPa}\right) /$ $\mathrm{Pt}(+)$

the temperature range under study. There is no thermodynamic data on $\mathrm{Dy}_{2} \mathrm{Ru}_{2} \mathrm{O}_{7}(\mathrm{~s})$ in the literature for comparing the results obtained in this study.

\subsection{Standard molar heat capacity of $\mathrm{Dy}_{2} \mathrm{Ru}_{2} \mathrm{O}_{7}(\mathrm{~s})$}

The heat capacities of $\mathrm{Dy}_{2} \mathrm{Ru}_{2} \mathrm{O}_{7}(\mathrm{~s})$, were measured in the temperature range from $174 \leq T(\mathrm{~K}) \leq 305$, were taken at ambient pressure, $101.3 \mathrm{kPa}$, using a differential scanning calorimeter and are given in Fig. 2 . The values of heat capacities were best fitted in the following polynomial expression by the least squares method.

$$
\begin{aligned}
& C_{\mathrm{p}}^{\circ}\left(\mathrm{Dy}_{2} \mathrm{Ru}_{2} \mathrm{O}_{7}, \mathrm{~s}, \mathrm{~T}\right)\left(\mathrm{J} \mathrm{K}^{-1} \mathrm{~mol}^{-1}\right) \\
& \quad=235.09+3.99 \times 10^{-2} \mathrm{~T}(\mathrm{~K})-10.53 \times 10^{5} / \mathrm{T}^{2}(\mathrm{~K}) .
\end{aligned}
$$

At $298.15 \mathrm{~K}$, the standard molar heat capacity of $\mathrm{Dy}_{2} \mathrm{Ru}_{2} \mathrm{O}_{7}(\mathrm{~s})$ was calculated to be $235.2 \mathrm{~J} \mathrm{~K}^{-1} \mathrm{~mol}^{-1}$. Neumann-Kopp's rule estimates the heat capacity and gives the heat capacity at $298.15 \mathrm{~K}_{\text {of }} \mathrm{Dy}_{2} \mathrm{Ru}_{2} \mathrm{O}_{7}(\mathrm{~s})$ as $222.3 \mathrm{~J} \mathrm{~K}^{-1} \mathrm{~mol}^{-1}$ [24]. This data for $\mathrm{Dy}_{2} \mathrm{Ru}_{2} \mathrm{O}_{7}(\mathrm{~s})$ has been reported for the first time. Based on the estimated entropy value of $\mathrm{Dy}_{2} \mathrm{Ru}_{2} \mathrm{O}_{7}(\mathrm{~s})$ and the measured heat capacity, the thermodynamic

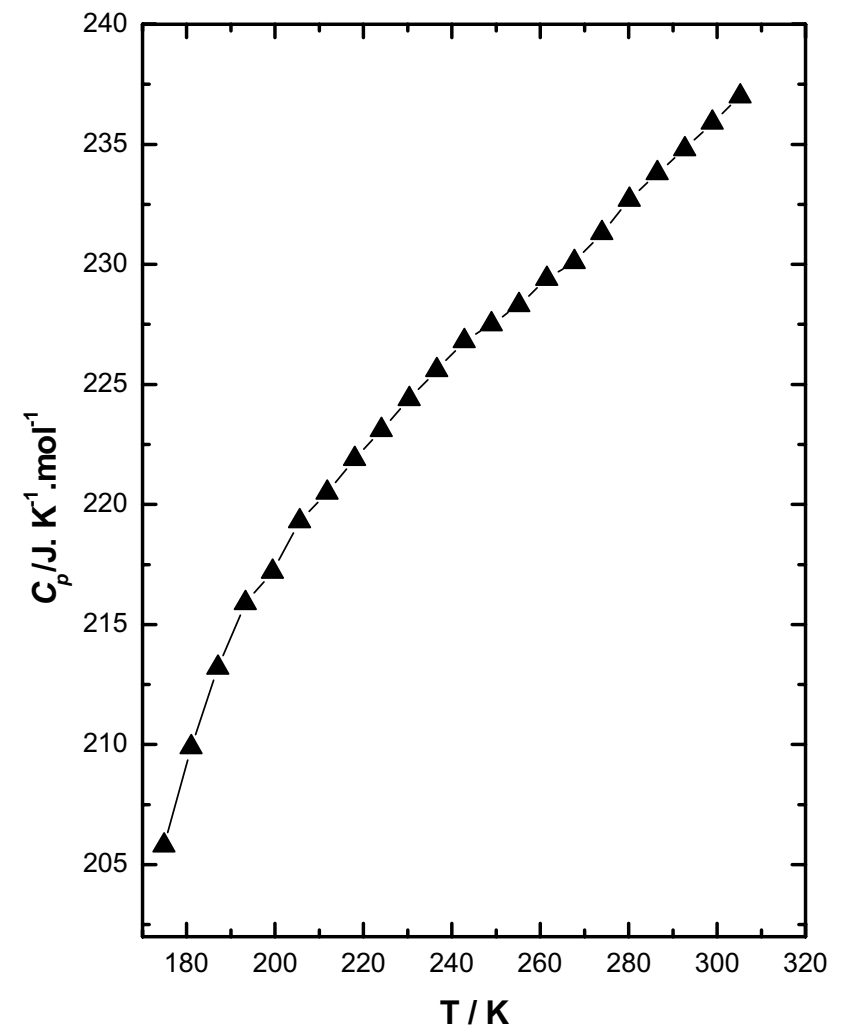

Fig. 2 Plot of molar heat capacity of Dy2Ru2O7(s) against temperature

Table 1 Derived high temperature thermodynamic functions of $\mathrm{Dy}_{2} \mathrm{Ru}_{2} \mathrm{O}_{7}(\mathrm{~s})$

\begin{tabular}{lrlll}
\hline$T$ & $\begin{array}{l}\mathrm{H}_{\mathrm{T}}^{\circ} \mathrm{H}_{298.15}^{\circ} \\
(\mathrm{K})\end{array}$ & $\begin{array}{l}\mathrm{C}_{\mathrm{p}, \mathrm{m}}^{\circ} \\
\left(\mathrm{J} \mathrm{mol}^{-1}\right)\end{array}$ & $\begin{array}{l}\mathrm{S}_{m}{ }^{\circ}(\mathrm{T}) \\
\left(\mathrm{J} \mathrm{K}^{-1} \mathrm{~mol}^{-1}\right)\end{array}$ & $\begin{array}{l}\mathrm{fef}^{\mathrm{a}} \\
\left(\mathrm{J} \mathrm{K}^{-1} \mathrm{~mol}^{-1}\right)\end{array}$ \\
\hline 300.0 & 437.6 & 235.4 & 255.5 & 254.0 \\
350.0 & $12,339.4$ & 240.5 & 292.1 & 256.9 \\
400.0 & $24,466.5$ & 244.5 & 324.5 & 263.4 \\
450.0 & $36,776.9$ & 247.9 & 353.5 & 271.8 \\
500.0 & $49,245.9$ & 250.9 & 379.8 & 281.3 \\
550.0 & $61,857.2$ & 253.6 & 403.8 & 291.4 \\
600.0 & $74,600.4$ & 256.1 & 426.0 & 301.7 \\
650.0 & $87,467.9$ & 258.6 & 446.6 & 312.0 \\
700.0 & $100,454.6$ & 260.9 & 465.8 & 322.3 \\
750.0 & $113,556.6$ & 263.2 & 483.9 & 332.5 \\
800.0 & $126,770.9$ & 265.4 & 501.0 & 342.5 \\
850.0 & $140,095.5$ & 267.6 & 517.1 & 352.3 \\
900.0 & $153,528.5$ & 269.7 & 532.5 & 361.9 \\
950.0 & $167,168.6$ & 271.9 & 547.1 & 371.3 \\
1000.0 & $180,714.7$ & 273.9 & 561.1 & 380.4 \\
\hline
\end{tabular}

Free energy function $\left(\mathrm{fef}^{\mathrm{a}}\right)=-\left\{G^{\circ}(T)-H^{\circ}(298.15 \mathrm{~K})\right\} / T$ 
functions for $\mathrm{Dy}_{2} \mathrm{Ru}_{2} \mathrm{O}_{7}(\mathrm{~s})$ were calculated and are given in Table 1. The Gibbs energy data obtained in this study was used to calculate the decomposition temperature of $\mathrm{Dy}_{2} \mathrm{Ru}_{2} \mathrm{O}_{7}(\mathrm{~s})$ and is $1769 \mathrm{~K}$ in air. The decomposition temperature of $\mathrm{RuO}_{2}(\mathrm{~s})$ was calculated from the Gibbs free energy data of and is $1647 \mathrm{~K}$. The decomposition temperature of $\mathrm{Dy}_{2} \mathrm{Ru}_{2} \mathrm{O}_{7}(\mathrm{~s})$ is higher than that of $\mathrm{RuO}_{2}(\mathrm{~s})$ as determined by Cordfunke [25], indicating higher stability for $\mathrm{Dy}_{2} \mathrm{Ru}_{2} \mathrm{O}_{7}(\mathrm{~s})$.

\section{Conclusions}

In summary, the ternary oxide $\mathrm{Dy}_{2} \mathrm{Ru}_{2} \mathrm{O}_{7}(\mathrm{~s})$, in the Dy-Ru-O system was prepared by the solid-state synthesis route. The Gibbs energies of formation of the ternary compound was obtained by using electrochemical oxide cell at high temperature. The Gibbs energy of formation of $\mathrm{Dy}_{2} \mathrm{Ru}_{2} \mathrm{O}_{7}(\mathrm{~s})$ from elements in their standard state is given by: $\left\{\Delta_{\mathrm{f}} G^{\circ}\left(\mathrm{Dy}_{2} \mathrm{Ru}_{2} \mathrm{O}_{7}, \mathrm{~s}\right) /\left(\mathrm{kJ} \mathrm{mol}^{-1}\right) \pm 4.4\right\}=-2505+0.627$. $(T / K)$. Heat capacity is one of the essential thermophysical characterizations that determine thermal behavior of the material. The heat capacity was measured using a differential scanning calorimeter and the heat capacity of $\mathrm{Dy}_{2} \mathrm{Ru}_{2} \mathrm{O}_{7}(\mathrm{~s})$ at $298.15 \mathrm{~K}$ was determined to be $235.2 \mathrm{~J} \mathrm{~K}^{-1} \mathrm{~mol}^{-1}$. The decomposition temperature of $\mathrm{Dy}_{2} \mathrm{Ru}_{2} \mathrm{O}_{7}(\mathrm{~s})$ is higher than that of $\mathrm{RuO}_{2}(\mathrm{~s})$, indicating stability of the former. The determination of thermodynamic parameters for $\mathrm{Dy}_{2} \mathrm{Ru}_{2} \mathrm{O}_{7}(\mathrm{~s})$ will pave the way for a study on the systematic trends in stability of $\mathrm{Ln}_{2} \mathrm{Ru}_{2} \mathrm{O}_{7}(\mathrm{~s})$ as a function of ionic radii down the lanthanide series.

Acknowledgements The author is thankful to Dr. S Kannan, Head Fuel Chemistry Division and Dr. P. K. Pujari, Director R C \& I Group, for their constant support and encouragement.

\section{Compliance with ethical standards}

Conflict of interest The author declares that there are no conflicts of interest.

\section{References}

1. Pace S, Cannillo V, Wu J, Boccaccini DN, Seglem S, Boccaccini AR (2005) Processing glass-pyrochlore composites for nuclear waste encapsulation. J Nucl Mater 341:12-18

2. Ashcroft AT, Cheetham AK, Ford JS, Green MLH, Grey CP, Murrell AJ, Vernon PDF (1990) Selective oxidation of methane to synthesis gas using transition metal catalysts. Nature 344:319-321

3. Kim J, Shih PC, Tsao KC, Pan YT, Yin X, Sun CJ, Yang H (2017) High-performance pyrochlore-type yttrium ruthenate electrocatalyst for oxygen evolution reaction in acidic media. J Am Chem Soc 139:12076-12083

4. Cao XQ, Vassen R, Jungen W, Schwartz S, Tietz F, Stover D (2001) Thermal stability of lanthanum zirconate plasma-sprayed coating. J Am Ceram Soc 84:2086-2090

5. Bouchard RJ, Gillson JL (1971) A new family of bismuth - precious metal pyrochlores. Mater ResBull 6:669-679
6. Taira N, Wakeshima M, Hinatsu Y (2002) Magnetic susceptibility and specific heat studies on heavy rare earth ruthenate pyrochlores $\mathrm{R}_{2} \mathrm{Ru}_{2} \mathrm{O}_{7}(\mathrm{R}=\mathrm{Gd}-\mathrm{Yb})$. J Mater Chem 12:1475-1479

7. Wang SX, Begg BD, Wang LM, Ewing RC, Weber WJ, Govindan Kutty KV (1999) Radiation stability of gadolinium zirconate: A waste form for plutonium disposition. J Mater Res 14(12):4470-4473

8. Parrondo J, George M, Capuano C, Ayers KE, Ramani V (2015) Pyrochlore electrocatalysts for efficient alkaline water electrolysis. J Mater Chem A 3:10819-10828

9. Cox PA, Egdell RG, Goodenough JB, Hamnett A, Naish CC (1983) The metal-to-semiconductor transition in ternary ruthenium (IV) oxides: a study by electron spectroscopy. J Phys C Solid State Phys 16:32

10. Xu ZC, Liu MF, Lin L, Liu H, Yan ZB, Liu JM (2014) Experimental observations of ferroelectricity in double pyrochlore $\mathrm{Dy}_{2} \mathrm{Ru}_{2} \mathrm{O}_{7}$. Front Phys 9(1):82-89

11. Sodderholm L, Stager CV, Greedan JE (1982) Crystal field effects on the magnetic behavior of $\mathrm{Yb}_{2} \mathrm{~V}_{2} \mathrm{O}_{7}$ and $\mathrm{Tm}_{2} \mathrm{~V}_{2} \mathrm{O}_{7}$. J Solid State Chem 43:175-180

12. Ito $M$, Yasui $Y$, Kanada Harashina Yoshii HS, Murata K, Sato M, Okumura $\mathrm{H}$, Kakurai K (2001) Nature of spin freezing transition of geometrically frustrated pyrochlore system $\mathrm{R}_{2} \mathrm{Ru}_{2} \mathrm{O}_{7}(\mathrm{R}=$ rare earth elements and Y). J Phys Chem Solids 62:337-341

13. Yao LR, Wang D, Peng W, Hu WW, Yuan HM, Feng SH (2011) Hydrothermal synthesis and characterization of rare-earth ruthenate pyrochlore compounds $\mathrm{R}_{2} \mathrm{Ru}_{2} \mathrm{O}_{7}\left(\mathrm{R}=\mathrm{Pr}^{3+}, \mathrm{Sm}^{3+}\right.$ $\left.\mathrm{Ho}^{3+}\right)$. Sci China Chem 54(6):941-946

14. Bansal $C$, Kawanaka $H$, Bando $H$, Nishihara $Y$ (2003) Magnetic properties of $\mathrm{Ho}_{2} \mathrm{Ru}_{2} \mathrm{O}_{7}$ and $\mathrm{Dy}_{2} \mathrm{Ru}_{2} \mathrm{O}_{7}$ pyrochlores. Physica $\mathrm{B}$ 329(2):1034-1035

15. Banerjee $A$ (2013) System $\mathrm{Er}-\mathrm{Ru}-\mathrm{O}$ : high temperature study of the heavy rare earth pyrochlore $\mathrm{Er}_{2} \mathrm{Ru}_{2} \mathrm{O}_{7}$ (s) by electrochemical cell and differential scanning calorimeter. Solid State Ion 253:70-75

16. Yamamoto $Y$, Kanno R, Takeda $Y$, Yamamoto O, Kawamoto $Y$, Takano MJ (1994) Crystal structure and metal-semiconductor transition of the $\mathrm{Bi}_{2-x} \mathrm{Ln}_{x} \mathrm{Ru}_{2} \mathrm{O}_{7}$ pyrochlores. $(\mathrm{Ln}=\mathrm{Pr}-\mathrm{Lu})$. Solid State Chem 109:372-383

17. Banerjee A, Singh Z, Venugopal V (2009) Heat capacity and Gibbs energy of formation of the ternary oxide $\mathrm{CdRh}_{2} \mathrm{O}_{4}$ (s. Solid State Ionics 180:1337-1341

18. Pratt JN (1990) Applications of solid electrolytes in thermodynamic studies of materials: A review. Metall Trans A 21:1223-1235

19. Rakshit SK, Parida SC, Dash S, Singh Z, Venugopal V (2006) Thermodynamics of $\mathrm{BaNd}_{2} \mathrm{Fe}_{2} \mathrm{O}_{7}(\mathrm{~s})$ and $\mathrm{BaNdFeO}_{4}(\mathrm{~s})$ in the system BaNdFeO. Thermochim Acta 443:98-104

20. Sabbah R, Xu-wu A, Chickos JS, Planas Leitao ML, Roux MV, Torres LA (1999) Reference materials for calorimetry and differential thermal analysis. Thermochim Acta 331:93

21. Hohne GWH, Hemminger WF, Flammershein HJ (2003) Differential scanning calorimetry, 2nd edn. Springer, Berlin

22. Chase MW Jr (1982) JANAF thermochemical tables, fourth ed. J Phys Chem 11(3):695-940 (monograph no. 91995)

23. FactSage, version 5.3.1 (1976-2004) Thermo-chemical database software, Thermfact. GTT Technologies, Herzogenrath

24. Kubachewski O, Alcock CB, Spencer PJ (1993) Materials thermochemistry, 6th edn. Pergamon, Oxford

25. Cordfunke EHP, Konings RJM (1988) The enthalpy of formation of $\mathrm{RuO}_{2}$. Thermochim Acta 129:63-69

Publisher's Note Springer Nature remains neutral with regard to jurisdictional claims in published maps and institutional affiliations. 